\title{
Efek Antifertilitas Ekstrak Biji Pepaya (Carica Papaya L.) dengan Pelarut Air terhadap Bobot Anak Mencit (Mus Musculus L.)
}

\section{The Antifertility Effects of Papaya Seeds (Carica Papaya L.) Extract with Dilution Water on Mice (Mus Musculus L.) Litters}

\author{
Muhammad Farizan Adani ${ }^{1}$, Agung Janika Sitasiwi ${ }^{2}$, Sri Isdadiyanto ${ }^{2}$ \\ ${ }^{1)}$ Program Studi Biologi, Departemen Biologi, Fakultas Sains dan Matematika, Universitas Diponegoro \\ ${ }^{2)}$ Departemen Biologi, Fakultas Sains dan Matematika, Universitas Diponegoro \\ Jl. Prof. Soedarto, SH, tembalang, Semarang \\ *Email: agssiwi@yahoo.co.id
}

Diterima 11 Desember 2016/Disetujui 20 Februari 2017

\begin{abstract}
ABSTRAK
Biji pepaya merupakan tanaman obat yang diduga memiliki senyawa antifertilitas sehingga dapat dijadikan sebagai alat kontrasepsi herbal yang aman. Tujuan dari penelitian ini adalah untuk menguji efek antifertilitas ekstrak biji pepaya (C. papaya L.) dengan pelarut air terhadap bobot anak mencit (Mus musculus L.). Penelitian ini merupakan penelitian eksperimental dengan Rancangan Acak Lengkap (RAL), menggunakan 15 ekor mencit betina yang dibagi ke dalam 5 kelompok perlakuan dengan 3 kali ulangan. $\mathrm{K}(-)$ : bahan perlakuan berupa aquades. $\mathrm{K}(+)$ : bahan perlakuan berupa pil kontrasepsi. P1, P2, P3 masing-masing diberi bahan perlakuan berupa ekstrak biji pepaya dengan dosis 1,4, 3,5, $7 \mathrm{mg} / \mathrm{ekor} / \mathrm{hari}$. Masing-masing diberikan perlakuan oral dengan volume $0,5 \mathrm{ml}$ selama 21 hari. Setelah perlakuan berakhir, dilanjutkan dengan uji kawin. Parameter yang diamati adalah bobot anak mencit, bobot induk mencit setelah perlakuan berakhir. Data yang diperoleh dianalisis menggunakan Analysis of Variance (ANOVA) pada taraf kepercayaan 95\%. Hasil penelitian menunjukkan bahwa perlakuan memberikan pengaruh berbeda tidak nyata terhadap bobot anak mencit dan induk mencit. Kesimpulan penelitian ini adalah senyawa antifertilitas dalam biji pepaya (C. papaya L.) dengan pelarut air tidak mempengaruhi bobot anak dan induk mencit.
\end{abstract}

Kata kunci : Carica papaya, antifertilitas, bobot anak mencit, bobot induk mencit

\begin{abstract}
Papaya seeds were known as medicinal plants which was believed have antifertility compounds that can be used as herbal contraceptives. The purpose of this study was to test the effect of antifertility of papaya seeds (Carica papaya L.) extract with dilution water on mice (Mus musculus L.) litters weight. This study was designed by Completely Randomized Design (CRD) with 5 treatment groups with 3 replicates respectively. $\mathrm{K}(-)$ : negative control group were administered aquades. $\mathrm{K}(+)$ : positive control group were administered contraceptive pills. P1 to P3 groups were administered 1,4, 3,5 and $7 \mathrm{mg} /$ animal/day. Each treatment were given orally for 21 days with $0.5 \mathrm{ml}$ in volume. After treatment were terminated, followed by mating test. The parameters observed were weights of litters and breeders mice. Data were analyzed using Analysis of Variance (ANOVA) at 95\% levels. The results showed that the treatment effect was not significantly different on mice litters and breeders weight. It could be concluded that the treatment of water extract of papaya seeds did not affects the mice litters weights.
\end{abstract}

Keywords : Carica papaya, antifertility, litters weight, breeders weight 


\section{PENDAHULUAN}

Kontrasepsi merupakan suatu cara untuk mencegah terjadinya kehamilan (Prawirohardjo dan Sawarno, 2006). Kontrasepsi dapat dilakukan dengan menggunakan alat atau obat-obatan. Macam-macam kontrasepsi alat yaitu; kondom, IUD atau spiral, dan implan. Macam-macam kontrasepsi obat-obatan yaitu; kontrasepsi suntik dan pil kontrasepsi (Mochtar, 1996).

Hasil riset membuktikan bahwa penggunaan metode kontrasepsi dapat menyebabkan kerugian kesehatan. Naser et al. (2009) menyatakan bahwa penggunaan kontrasepsi suntik memiliki efek samping berupa gangguan pola menstruasi, kegemukan atau obesitas, sakit kepala, dan rasa ketidaknyamanan di perut. Sudibyo (2013) menyatakan beberapa efek tersebut menjadi alasan pemutusan pemakaian kontrasepsi. BKKBN (2014) menyatakan terdapat peningkatan jumlah peserta KB yang berhenti atau drop out.

Banyak tanaman disekitar kita yang memiliki khasiat yang luar biasa. Joshi et al. (2011) menyatakan bahwa zat tumbuhan alami memiliki sifat estrogenik yang cukup kuat sehingga berpeluang dijadikan kontrasepsi herbal yang aman digunakan.

Walansendow dkk. (2016) menyatakan bahwa Indonesia kaya akan tanaman obat, salah satunya adalah tanaman pepaya. Tanaman pepaya merupakan tanaman yang bernilai ekonomis dan kaya akan manfaat, mulai dari daun sampai akar dapat dimanfaatkan dalam kehidupan manusia. Meskipun bagian-bagian pepaya banyak dimanfaatkan dalam berbagai bidang, tetapi manfaat biji pepaya masih belum banyak diketahui masyarakat.

Hasil penelitian Siburian dkk. (2008) mengenai biji pepaya menunjukkan bahwa biji pepaya diduga mengandung senyawa bersifat antifertilitas. Hasil penelitian Adebiyi et al. (2003) menyatakan bahwa pengaruh senyawa benzyl isothiocynate (BITC) pada ekstrak biji pepaya terhadap jaringan uterus tikus betina terbukti mempengaruhi struktur miometrium dan endometrium uterus pada tikus betina. Punitha et al. (2015) membuktikan tikus betina diberikan kombinasi pulp buah pepaya dan ekstrak biji pepaya menunjukkan gangguan epitel endometrium, lipatan endometrium terganggu, menyusut dan terjadi pengurangan jumlah kelenjar uterus.

Penelitian ini dilakukan untuk menguji efek antifertilitas ekstrak biji pepaya ( $C$. papaya L.) dengan pelarut air terhadap bobot anak mencit (Mus musculus L.).

\section{METODE PENELITIAN}

\section{Alat dan Bahan}

Bahan uji adalah biji pepaya yang berasal dari satu pohon. Pil kontrasepsi merk $\mathrm{X}$ digunakan sebagai bahan uji dalam kelompok kontrol positif. Hewan uji yang digunakan adalah mencit betina galur Swiss Webster berumur 2,5 bulan.

Alat yang digunakan yaitu seperangkat kandang pemeliharaan dan perlengkapannya, sekam padi, neraca Ohaus, neraca analitik, pinset, jarum gavage, spuit volume $1 \mathrm{ml}$, cawan petri, tabung erlenmeyer, gelas ukur, kompor listrik, blender, oven, tempat pakan dan tempat minum.

\section{Pembuatan Ekstrak Biji Pepaya}

Biji dicuci bersih dengan air mengalir. Setelah dicuci, biji dikeringkan dengan oven pada suhu $45-50^{\circ} \mathrm{C}$ sampai kering. Biji yang telah kering, dibuat tepung dengan cara dihancurkan dengan blender, kemudian diayak. Tepung ditimbang sesuai dosis yang ditentukan untuk perlakuan.

\section{Menentukan Konsentrasi Bahan Uji}

Dosis yang pernah diuji menggunakan hewan uji tikus adalah sebesar $10 \mathrm{mg} / \mathrm{ekor}$ dan $50 \mathrm{mg} / \mathrm{ekor}$ (Lohiya et al.,1994). Dosis perlakuan untuk ditentukan berdasar angka konversi sebesar 0.14 (Laurence and Bacharach, 1964) sehingga dosis untuk mencit yang didapat adalah 1,4 $\mathrm{mg}, 3,5 \mathrm{mg}$ dan $7 \mathrm{mg}$.

Pembuatan sediaan pil kontrasepsi dengan dasar konversi dosis manusia ke mencit sebesar 0,00261 (Laurence and Bacharach, 1964). Berdasar angka konversi tersebut, dosis untuk mencit ditentukan dengan cara mengencerkan 1 tablet dalam 7,16 ml air akuades. Pengenceran dilakukan dengan cara menghancurkan tablet dan melarutkan dalam air hangat. 


\section{Cara Perlakuan Hewan Uji}

Mencit betina dipelihara pada kandang terpisah dengan mencit jantan, masing-masing dengan kepadatan 3 ekor per kandang. Aklimasi dalam kondisi laboratorium dilakukan selama 2 minggu. Pemberian pakan dan minum dilakukan secara ad libitum.

Perlakuan oral hewan uji dilakukan dengan memberikan dosis yang telah ditentukan dengan volume $0,5 \mathrm{ml}$ per hewan uji. Pemberian bahan uji dilakukan pada sore hari (jam 15.00-16.00), selama 21 hari berturut-turut. Bobot badan mencit diukur selama 7 hari sekali.

Hewan uji di kawinkan pada akhir perlakuan dengan cara menggabungkan 3 ekor betina dengan 1 ekor jantan dalam 1 kandang. Setelah, hewan uji dikawinkan, dilakukan pengamatan mencit betina yang bunting. Mencit betina yang kawin ditandai ada atau tidaknya vaginal plug/sumbat vagina pada pagi hari. Vaginal plug merupakan pedoman untuk menentukan hari pertama kebuntingan (Sitasiwi dan Djaelani, 2011). Mencit yang telah bunting dipelihara sampai melahirkan.

\section{HASIL DAN PEMBAHASAN}

Hasil pengaruh pemberian ekstrak biji pepaya dengan pelarut air terhadap bobot anak mencit, dan bobot induk mencit disajikan pada Tabel 4.1.

Hasil ANOVA yang disajikan pada Tabel 1. mengenai pengaruh pemberian ekstrak biji pepaya dengan pelarut air terhadap bobot anak mencit menunjukkan hasil tidak berbeda nyata $(\mathrm{P}>0,05)$.

Berdasarkan hal tersebut di atas, dapat diasumsikan bahwa pemberian senyawa antifertilitas ekstrak biji pepaya dengan pelarut air tidak berpengaruh terhadap bobot anak dan bobot induk mencit.

Bobot anak mencit dalam penelitian ini tidak dipengaruhi oleh paparan bahan uji. Anak mencit pada umumnya memiliki bobot badan berkisar antara 0,5-1,5 g/ekor (Malole dan Pramono, 1989). Hasil penelitian ini menunjukkan kisaran rerata bobot anak mencit pada seluruh kelompok perlakuan adalah 1,34-1,42 g, sehingga dapat diasumsikan bahwa bobot anak mencit masih dalam kisaran normal.

Senyawa antifertilitas ekstrak biji pepaya dalam penelitian ini tidak mempengaruhi bobot anak mencit. Hal ini diduga konsentrasi senyawa antifertilitas yang masuk ke dalam proses metabolisme tidak tinggi. Penyebab lain diduga adanya konsentrasi senyawa dalam air relatif sedikit, karena dosis ekstrak biji pepaya yang diberikan juga relatif kecil sehingga senyawa tersebut diduga tidak mengganggu bobot anak mencit. Hal lain yang diduga menjadi penyebab bobot anak mencit berbeda tidak nyata adalah proses detoksifikasi yang terjadi dalam hepar terhadap bahan uji yang diberikan.

Biji pepaya mengandung beberapa senyawa yang diduga berpotensi sebagai senyawa antifertilitas. Naggayi et al. (2015) menyatakan terdapat beberapa senyawa pada biji pepaya yang dapat larut dalam air, yaitu; saponin, tanin, flavonol, glikosida, terpenoid, alkaloid, pereduksi gula, asam amino, lemak, protein, fenol, vitamin, sterol dan triterpenes. Adnan (1992) menyatakan senyawa dari tumbuhan dapat digunakan sebagai bahan antifertilitas umumnya berasal dari golongan steroid, alkaloid, flavonoid, sehingga senyawa yang diduga larut dalam ekstrak yang digunakan dalam penelitian adalah alkaloid dan flavanoid. Setyowati dkk. (2015) menyatakan senyawa golongan flavonoid dan alkaloid dapat menekan tingkat fertilitas dengan cara mengganggu fungsi ovarium, uterus atau vagina (Setyowati dkk., 2015).

Setyowati dkk. (2015) menyatakan senyawa alkaloid dapat menghambat proses terjadinya ovulasi dan meresorpsi fetus tikus sehingga bila diberikan pada masa kebuntingan, zat ini bisa mengganggu fetus yang ada di dalam uterus tikus. Alkaloid, terutama alkaloid steroid sangat mirip dengan saponin yang digunakan sebagai bahan dasar sintesis beberapa hormon steroid untuk bahan kontrasepsi oral. Senyawa flavonoid merupakan bahan aktif bersifat estrogenik atau menyerupai estrogen. Zat yang strukturnya analog hormon estrogen akan terikat pada reseptor hormon, tetapi tidak menstimulasi reseptor tersebut. Jika menempati reseptor hormon estrogen akibatnya aksi hormon pada sel target akan berkurang. 
Tabel 1. Hasil ANOVA pengaruh ekstrak biji pepaya dengan pelarut air terhadap bobot anak dan induk mencit

\begin{tabular}{lccccc}
\hline \multirow{2}{*}{ Parameter } & \multicolumn{5}{c}{ Perlakuan } \\
\cline { 2 - 6 } & $\mathrm{K}(-)$ & $\mathrm{K}(+)$ & $\mathrm{P} 1$ & $\mathrm{P} 2$ & $\mathrm{P} 3$ \\
& $\overline{\mathrm{x}} \pm \mathrm{SD}$ & $\overline{\mathrm{x}} \pm \mathrm{SD}$ & $\overline{\mathrm{x}} \pm \mathrm{SD}$ & $\overline{\mathrm{x}} \pm \mathrm{SD}$ & $\overline{\mathrm{x}} \pm \mathrm{SD}$ \\
\hline $\begin{array}{l}\text { Bobot anak } \\
\text { mencit (g) }\end{array}$ & $1,364^{\mathrm{a}} \pm 0,178$ & $1,355^{\mathrm{a}} \pm 0,044$ & $1,347^{\mathrm{a}} \pm 0,041$ & $1,422^{\mathrm{a}} \pm 0,095$ & $1,395^{\mathrm{a}} \pm 0,322$ \\
$\begin{array}{l}\text { Bobot } \\
\text { induk }\end{array}$ & $26,466^{\mathrm{a}} \pm 3,677$ & $28,366^{\mathrm{a}} \pm 1,274$ & $26,933^{\mathrm{a}} \pm 2,835$ & $25,833^{\mathrm{a}} \pm 1,665$ & $27,966^{\mathrm{a}} \pm 1,115$ \\
mencit (g) & & & & & \\
\hline
\end{tabular}

Keterangan : Angka yang diikuti dengan superskrip yang sama pada baris yang sama menunjukkan perbedaan tidak nyata $(\mathrm{P}>0,05) . \mathrm{K}(-)$ : Kontrol dengan pelarut bahan uji akuades $0,5 \mathrm{ml} / \mathrm{ekor} / \mathrm{hari} . \mathrm{K}(+)$ : Kontrol dengan bahan uji sediaan pil kontrasepsi dosis $0,2 \mathrm{mg} / \mathrm{ml} / \mathrm{ekor} /$ hari. P1: Perlakuan dengan bahan uji konsentrasi 1,4 mg/ml/ekor/hari. P2: Perlakuan dengan bahan uji konsentrasi 3,5 mg/ml/ekor/hari. P3: Perlakuan dengan bahan uji konsentrasi $7 \mathrm{mg} / \mathrm{ml} /$ ekor/hari.

Mekanisme masuknya senyawa antifertilitas dari ekstrak biji pepaya dimulai dari terjadinya penyerapan senyawa oleh dinding intestinum yang terdapat pembuluh kapiler. Pembuluh kapiler kemudian mengalirkan darah ke dalam vena porta. Iskandar (2002) menyatakan senyawa dalam bahan uji diserap ke dalam dinding usus yang terdapat pembuluh kapiler. Pembuluh kapiler mengalirkan darah ke dalam vena yang bergabung dengan vena yang lebih besar dan pada akhirnya masuk ke dalam hepar sebagai vena porta. Senyawa antifertilitas dari vena porta dialirkan ke seluruh tubuh, termasuk ke dalam endometrium hewan uji.

Darah yang membawa senyawa antifertilitas yang masuk ke dalam hepar, juga mengalami detoksifikasi. Hal tersebut menyebabkan senyawa antifertilitas yang diduga memiliki sifat toksik menjadi rendah toksisitasnya sehingga tidak mempengaruhi bobot anak mencit. Arief (2007) menyatakan fungsi hepar sebagai pusat detoksifikasi tubuh terhadap berbagai macam bahan seperti bakteri, virus, parasit, zat racun, logam berat dan obat over dosis. Senyawa antifertilitas dan nutrisi yang terkandung dalam darah di hepar, kemudian diedarkan ke seluruh tubuh dan digunakan oleh sel-sel tubuh sebagai bahan untuk proses metabolisme sebagai sumber tenaga, zat pembangun (struktural), dan molekul fungsionl (hormon dan enzim).

Hal tersebut diduga dialami oleh senyawa flavonoid, dimana senyawa flavonoid yang strukturnya menyerupai estrogen. Jika darah membawa flavonoid melawati hepar, ada kemungkinan di hepar senyawa tersebut diinaktivasi sebelum masuk sistem sirkulasi, sehingga senyawa flavonoid kurang bekerja dengan baik. Senyawa antifertilitas lain dalam bahan uji yang memiliki kemiripan seperti hormon steroid, yaitu alkaloid, di dalam hepar akan diolah menjadi senyawa yang tidak aktif dan larut dalam air. Mary dkk. (2005) menyatakan hepar memodifikasi atau membuat banyak hormon menjadi tidak aktif. Hormon steroid (kortisol, estrogen, progesteron, testosteron, aldosterone dan senyawa mirip dengan steroid) diolah hepar menjadi larut dalam air sehingga lebih mudah diekskresikan. Mekanisme tersebut diduga menyebabkan efek yang berbeda tidak nyata antara kelompok perlakuan dan kelompok kontrol positif maupun negatif.

Hasil penelitian juga menunjukkan bahwa potensi bahan uji relatif sama dengan sediaan pil kontrasepsi yang digunakan dalam kelompok kontrol positif. Sitasiwi dan Mardiati (2016) menyatakan bahwa pil kontrasepsi mengandung estrogen dan progesteron sintetik. Estrogen sintetik dalam bahan uji adalah ethynil estradiol dan levonorgestrel Ethynil estradiol memiliki strukturnya yang sama dengan estrogen, tetapi memiliki aktivitas rendah dalam tubuh jika diberikan lewat digesti. Estrogen sintetik tersebut dibawa oleh vena porta dan masuk ke hepar, di hepar hormon tersebut diinaktivasi sebelum masuk sistem sirkulasi. Levonorgestrel adalah progesteron sintetik yang terkandung dalam pil kontrasepsi. Ganong (2003) menyatakan bahwa levonorgestrel merupakan progesteron sintetik, memiliki 
efektivitas yang tinggi dan dapat ditoleransi dengan baik oleh tubuh. Hal tersebut diduga menyebabkan lapisan endometrium uterus hewan uji masih bisa digunakan untuk perkembangan embrio.

Tabel 1. menunjukkan bahwa pertambahan bobot badan induk mencit tidak berbeda nyata $(\mathrm{P}>0,05)$ pada semua kelompok hewan uji. Hal ini menunjukkan bahwa perlakuan pemberian ekstrak biji pepaya dengan pelarut air maupun pemberian pil kontrasepsi dengan dosis kronis pada mencit tidak mempengaruhi bobot badan hewan uji. Smith dan Mangkoewidjojo (1988) menyatakan bobot badan mencit betina dewasa pada umumnya berkisar 18-35 g. Hasil penelitian ini menunjukkan kisaran rerata bobot induk mencit diantara 25-28 g, sehingga masih dalam kisaran normal. Hal ini dapat diartikan senyawa dalam biji pepaya tidak mempengaruhi penyerapan nutrisi yang diberikan terhadap induk mencit selama paparan bahan uji berlangsung.

Penyerapan nutrisi yang diduga tidak terpengaruh tersebut menyebabkan nutrisi yang terkandung dalam pakan yaitu protein $17,5-19,5 \%$, lemak $3 \%$, serat $8 \%$, abu $7 \%$, kalsium $0,90 \%$ dan pospor $0,60 \%$ terserap relatif sempurna serta dimetabolisir dengan baik sehingga bobot badan mencit tidak terganggu. Hewan uji pada semua kelompok dalam penelitian ini mendapatkan nutrisi yang sama. Mardiati dan Sitasiwi (2016) menyatakan pertambahan bobot badan pada suatu individu dipengaruhi oleh faktor nutrisi. Nutrisi pada dasarnya adalah zat gizi yang terdapat dalam pakan yang masuk ke dalam tubuh individu sebagai konsumsi pakan. Senyawa antifertilitas dalam bahan uji diduga tidak mempengaruhi metabolisme nutrisi, perubahan anabolik maupun nafsu makan sehingga memberikan perbedaan tidak nyata.

\section{KESIMPULAN}

Senyawa antifertilitas dalam ekstrak biji pepaya (Carica papaya L.) dengan dosis $1,4 \mathrm{mg}$, $3,5 \mathrm{mg}$, dan $7 \mathrm{mg}$ tidak mempengaruhi bobot anak dan induk mencit.

Penelitian lebih lanjut dapat dilakukan dengan meningkatkan konsentrasi dosis ekstrak biji pepaya dengan pelarut air yang digunakan dalam perlakuan untuk mengetahui kadar optimum menyebabkan penurunan bobot anak mencit sebagai antifertilitas reproduksi.

\section{DAFTAR PUSTAKA}

Adebiyi, A., P.G. Adaikan and R.N. Prasad. 2003. Tocolytic and toxic activity of papaya seed extract on isolated rat uterus. Life Sci. 74(5): 581-592.

Arief, S. 2007. Radikal Bebas. Ilmu Kesehatan Anak. Surabaya : FK UNAIR.

Bala, K., M. Arya and D.P. Katare. 2014. Herbal contraceptive: An overview. World Journal of Pharmacy and Pharmaceutical Science. 3(8): 13091326.

BKKBN. 2014. Kesertaan Keluarga Berencana dan faktor-faktor yang Berhubungan dengan Terjadinya Unmet/Need KB pada Pasangan Usia Subur di Kota Yogyakarta. Jakarta: Pusat Penelitian dan Pengembangan Kependudukan.

Joshi, M., K. Gaonkar, S. Mangoankar and S. Satarkar. 2011. Pharmacological investigation of Areca catechu extracts for evaluation of learning, memory, and behavior in rats. International Current Pharmaceutical Journal. 1(6):128-132.

Laurence D.R. and A.L. Bacharach. 1964. Evaluation of Drug Activities: Pharmacometrics.London: Academic Press.

Mardiati, S.M. dan A.J. Sitasiwi. 2016. Pertambahan berat badan mencit (Mus musculus L.) setelah perlakuan ekstrak air biji pepaya (Carica papaya Linn.) secara oral selama 21 hari. ejournal2.undip.ac.id.1(1): 1-6.

Naggayi M., N. Mukiibi and E. Iliya. 2015. The protective effects of aqueous extract of Carica papaya seeds in paracetamol induced nephrotoxicity in male wistar rats. African Health Sciences.15(2).

Naser, M., S.A. Ehab and Ahmed, S.G. 
2009. Why do depo provera users discontinue?. Journal of the royal medical services.16: 3 . kualitas spermatozoa tikus Wistar

(Rattus norvegicus). Jurnal eBiomedik (eBm). 4(1): 1-4.

Prawirohardjo dan Sarwono. 2006. Pelayanan Kesehatan Maternal dan Neonatal. Jakarta : YBP - SP.

Punitha, N., N. Shettu and R. Saravanan. 2015. Effect of Semi-Ripe Carica papaya Fruit Extracts on the Reproductive Structures in Female Albino Rats An Histological Study. International Journal of Current Research in Life Sciences. 4(6): 241-245.

Setyowati, E.A.W., D.R.S. Ariani, Ashadi, B. Mulyani, A. Hidayat. 2015. Aktivitas Antifertilitas Kontrasepsi Dari Kulit Durian (Durio zibethinus Murr.) Varietas Petruk. Program Studi Pendidikan Kimia Jurusan Fmipa Fkip Uns, Surakarta, 57-126.

Siburian, J., J. Marlina dan A. Johari. 2008. Pengaruh Ekstrak Biji Pepaya (Carica papaya L.) Pada Tahap Prakopulasi Terhadap Fungsi Reproduksi Mencit (Mus musculus L.) Swiss Webster Betina. Laporan Penelitian. PS Pendidikan Biologi Jurusan Pendidikan MIPA FKIP Universitas Jambi.1: 1-5.

Sitasiwi, A.J. dan M.A. Djaelani. 2011. Studi awal upaya eksplorasi agensia imunokontrasepsi untuk regulasi fertilitas hewan liar: Profil protein selama proses implantasi embrio mencit (Mus musculus L.) BALB/c. BIOMA. 13(1): 39 - 45.

Sitasiwi, A.J. dan S.M. Mardiati. 2016. Efek antifertilitas ekstrak air dari biji Carica papaya terhadap keteraturan siklus estrus Mencit (Mus musculus L.). ejournal2.undip.ac.id.1(1): 1-7.

Sudibyo, A. 2013. Angka Perceraian di Indonesia Tertinggi di Asia-Pasifik. BKKBN Online http://www.bkkbn.go. diakses pada tanggal 28 juni 2016.

Walansendow, R., Janette M, R. dan Lydia, T. 2016. Pengaruh pemberian ekstrak biji pepaya (Carica papaya L.) terhadap 